\title{
Ex vivo HR-MAS Magnetic Resonance Spectroscopy of human gastric adenocarcinomas: A comparison with healthy gastric mucosa
}

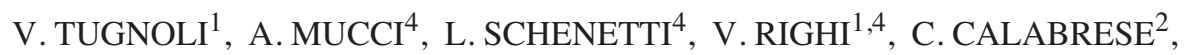 \\ A. FABBRI ${ }^{2}$, G. DI FEBO ${ }^{2}$ and M.R. TOSI ${ }^{3}$ \\ ${ }^{1}$ Dipartimento di Biochimica ‘G. Moruzzi', Università di Bologna, via Belmeloro 8/2, 40126 Bologna; ${ }^{2}$ Dipartimento \\ di Medicina Interna e Gastroenterologia, Università di Bologna, via Massarenti 9, 40138 Bologna; ${ }^{3}$ ITOI-CNR, \\ Sez. di Bologna, c/o IOR, via di Barbiano 1/10, 40136 Bologna; ${ }^{4}$ Dipartimento di Chimica, \\ Università di Modena e Reggio Emilia, via G. Campi 183, 41100 Modena, Italy
}

Received April 26, 2006; Accepted May 29, 2006

\begin{abstract}
The present study reports the characteristics of the biochemical profile of human gastric adenocarcinoma in comparison with that of healthy gastric mucosa, using ex vivo HR-MAS Magnetic Resonance Spectroscopy. Healthy human mucosa is mainly characterized by the presence of small metabolites (more than 50 identified) and macromolecules, whereas the adenocarcinoma spectra are dominated by the presence of signals due to triglycerides, whose content on the contrary is very low in healthy gastric mucosa. The use of spin-echo experiments enable us to detect some metabolites in the unhealthy tissues and to determine their variation with respect to the healthy ones. We have observed that the Cho:ChoCC ratio changes from 20:80 in the healthy tissues to $80: 20$ in the neoplastic gastric mucosa.
\end{abstract}

\section{Introduction}

Gastric cancer is the leading cause of cancer related death in many parts of the world (1). Gastric carcinogenesis is a multistep and multifactorial process that in many cases involves a progression from normal mucosa through chronic gastritis, atrophic gastritis and intestinal metaplasia to dysplasia and carcinoma (2). A number of pre-cancerous conditions such as atrophic gastritis and intestinal metaplasia have been recognised due to Helicobacter pylori (H. pylori) infection or autoimmunity and there are putative associations with environmental agents such as dietary constituents and

Correspondence to: Professor A. Mucci or Professor L. Schenetti, Dipartimento di Chimica, Università di Modena e Reggio Emilia, via G. Campi 183, 41100 Modena, Italy

E-mail:mucci.adele@unimo.it; schene@unimo.it

Key words: gastric cancer, gastric mucosa, ex vivo HR MAS Magnetic Resonance Spectroscopy, biochemical markers the formation of carcinogenic $N$-nitroso compounds within the stomach (3). The detection of early lesions, without lymph node involvement or distant metastases, would result in a reduction of mortality (4). Thus, achieving a better understanding of the molecular features of gastric cancer and the development of reliable methods for early detection is highly desirable.

In vivo Magnetic Resonance Spectroscopy (MRS) is a molecular investigation method well suited to the correlation of the biochemical composition of human tissues with their diseases with particular regard to neoplasms (5-7). The clinical impact of MRS in medicine has been widely reviewed by Smith and Steward (8) and is currently showing promise as a method that can complement routine diagnostic tools such as endoscopy and histopathology. It provides biochemical information, and it is thus in a position to detect early, pre-morphological molecular changes in tissue. Whereas organs, such as the brain, prostate, breast (5-7) have been widely studied, and MRS is used routinely in clinical medicine to analyse them, MRS in the evaluation of neoplasms of human gastric mucosa is in its infancy. In a previous study (9) we identified the molecular profile characteristics of the healthy human gastric mucosa. Ex vivo HR-MAS MRS performed at $9.4 \mathrm{~T}$ on gastric specimens collected during endoscopy, permitted the identification of more than 40 metabolites giving a detailed picture of the biochemical pattern of healthy gastric tissues. We hypothesised that the data will be used for a comparison with gastric pre-neoplastic and neoplastic situations. Moreover, the full knowledge of the biochemical pattern of these tissues is necessary for the application of MRS directly in vivo. In this context, a recent study assessing the clinical usefulness of ex vivo low resolution MRS in the evaluation of human gastric carcinomas was performed (10).

As part of a more comprehensive investigation on the biochemical characterisation of human healthy and neoplastic tissues through ex vivo HR-MAS MRS analysis $(9,11)$, we report a study aimed at elucidating the main metabolic characteristics of human adenocarcinomas in comparison with healthy gastric mucosa. To our knowledge 
only one report (10) exists on gastric adenocarcinoma obtained from low resolution ex vivo MR spectrum of the composite mucosal/submucosal layer and underlines that a decreased level of lipids together with an increased level of lactate and choline peaks is a marker for malignancy.

\section{Materials and methods}

Selection of the patients. Sixteen patients, 5 with gastric carcinoma ( 2 male, mean age 70.6 \pm 12.9 years, range 59-86 years) and 11 healthy subjects ( 7 male, mean age $49.3 \pm 17.3$ years, range 30-86 years) were evaluated. Of the 16 patients examined 14 underwent endoscopy, 2 underwent surgery for gastric adenocarcinoma; in all cases, sample of healthy gastric mucosa were collected.

All 5 patients with gastric cancer showed an $H$. pylori infection while no healthy subjects presented an $H$. pylori infection. Histological appearance was consistent with adenocarcinoma well differentiated in 3 patients, poorly differentiated and undifferentiated in one patient, respectively.

The patients gave written informed consent to participate in the study which was approved by the local research ethics committee. For each eligible patient, 8 biopsies were taken ( 4 biopsies from the antrum and 4 from the gastric body) during endoscopy. Among them, 4 were used for routine histological evaluation ( $\mathrm{H} \& \mathrm{E})$ and 4 were put in liquid nitrogen and stored at $-85^{\circ} \mathrm{C}$. Endoscopy was performed using the Olympus Videoendoscope 140 series and biopsy forceps (Olympus FB24Q), after sterilization in acetylacetic acid. The biopsies were obtained, on healthy tissues, in the subjects who did not present visible macroscopic alterations and the tissues were considered healthy only if the histological examination confirmed the macroscopic finding. The tissues were obtained from the mucosa and submucosal layer. In the patients with gastric cancer the biopsies were obtained from the lesion in the clearly macroscopic aspect of carcinoma and in normal appearing mucosa far from lesion. The gastric biopsies were fixed in neutral buffered formalin, routinely processed and stained with Giemsa and H\&E. The Goseki classification (12) was used for grading adenocarcinoma.

Tissue samples. The tissue samples were quickly frozen in liquid nitrogen after surgery to avoid microcrystallization of the water in the cell, causing damage and stored at $-85^{\circ} \mathrm{C}$, until MRS analysis. Before MRS analysis all samples were washed with $\mathrm{D}_{2} \mathrm{O}$, in order to eliminate the blood, prior to the insertion into the zirconia MAS rotor (4 mm OD). Sample and instrument preparation took $\sim 20 \mathrm{~min}$. Regarding sample 2, 9 pieces were selected in different places of the tissue, but the MR spectra did not show any significant differences.

Magnetic Resonance Spectroscopy. Proton HR-MAS MR spectra were recorded with a Bruker Avance400 spectrometer equipped with a ${ }^{1} \mathrm{H} /{ }^{13} \mathrm{C}$ HR-MAS probe operating at 400.13 and $100.61 \mathrm{MHz}$, respectively. Samples were spun at $4000 \mathrm{~Hz}$ and three different types of 1D proton spectra were acquired by using i) a composite pulse sequence (13) with a $1.5 \mathrm{sec}$ water-presaturation during relaxation delay, $8 \mathrm{kHz}$ spectral width, $32 \mathrm{k}$ data points, 32 scans, ii) a water- suppressed spin-echo Carr-Purcell-Meiboom-Gill (CPMG) sequence (14) with a $1.5 \mathrm{sec}$ water presaturation during relaxation delay, $1 \mathrm{msec}$ echo time $(\tau)$ and $360 \mathrm{msec}$ total spin-spin relaxation delay $(2 \mathrm{n} \tau), 8 \mathrm{kHz}$ spectral width, $32 \mathrm{k}$ data points, 256 scans and iii) a sequence for diffusion measurements based on stimulated echo and bipolar-gradient pulses (15) with big delta $200 \mathrm{msec}$, eddy current delay $\mathrm{T}_{\mathrm{e}} 5 \mathrm{~ms}$, little delta $2 * 2 \mathrm{msec}$, sine-shaped gradient with $32 \mathrm{G} / \mathrm{cm}$ followed by a $200 \mu \mathrm{sec}$ delay for gradient recovery, $8 \mathrm{kHz}$ spectral width, $8 \mathrm{k}$ data points, 256 scans. Two-dimensional (2D) ${ }^{1} \mathrm{H},{ }^{1} \mathrm{H}$-Correlation Spectroscopy (COSY) $(16,17)$ spectra were acquired using a standard pulse sequence and a $0.5 \mathrm{sec}$ water-presaturation during relaxation delay, $8 \mathrm{kHz}$ spectral width, $4 \mathrm{k}$ data points, 32 scans per increment, 256 increments. 2D ${ }^{1} \mathrm{H},{ }^{1} \mathrm{H}$-TOtal Correlation Spectroscopy (TOCSY) $(18,19)$ spectra were acquired using a standard pulse sequence and a $1 \mathrm{sec}$ water-presaturation during relaxation delay, $100 \mathrm{msec}$ mixing (spin-lock) time, $4 \mathrm{kHz}$ spectral width, $4 \mathrm{k}$ data points, 32 scans per increment, 128 increments. 2D ${ }^{1} \mathrm{H},{ }^{13} \mathrm{C}$-Heteronuclear Single Quantum Coherence (HSQC) $(20,21)$ spectra were acquired using a standard pulse sequence with echo-antiecho phase sensitive and $0.5 \mathrm{sec}$ relaxation delay, $1.725 \mathrm{msec}$ evolution time, $4 \mathrm{kHz}$ spectral width in $\mathrm{f}_{2}, 4 \mathrm{k}$ data points, 128 scans per increment, $17 \mathrm{kHz}$ spectral width in $\mathrm{f}_{1}, 256$ increments.

\section{Results and Discussion}

Conventional presaturated 1D spectra, representative of the healthy (trace a) and neoplastic (trace b) gastric mucosa are reported in Fig. 1. The healthy mucosa shows the presence of the resonances deriving from low molecular weight metabolites and macromolecules, whereas the adenocarcinoma is characterized by the presence of predominant signals due to triglycerides, whose content is very low in a healthy stomach. The MR spectra performed on 11 samples of healthy gastric mucosa confirm the metabolic profile detected in a previous study (9).

The complete characterisation of healthy mucosa was performed acquiring spin-echo sequence $\left[90^{\circ}-\left(\tau-180^{\circ}-\tau\right)_{n}\right]$, choosing $\tau$ and $\mathrm{n}$ in order to separate the signals according to their different $\mathrm{T} 2$ values allowing us to show the contribution due to mobile small molecules.

The full assignment of metabolites of the healthy tissues was performed, as already reported (9) through selected 2D experiments such as COSY, TOCSY and HSQC. The COSY and the TOCSY spectra are very informative for the identification of hidden resonances. The COSY spectra enable the coupled proton-proton pairs to be found, whereas the TOCSY spectra permit the identification of ${ }^{1} \mathrm{H}-{ }^{1} \mathrm{H}$ connectivities up to five or six bonds. ${ }^{1} \mathrm{H},{ }^{13} \mathrm{C}$ HSQC spectra were performed in order to identify the correlations between directly bonded carbon-proton pairs thus making possible the assignment of the singlets (which do not give correlations in homonuclear COSY and TOCSY spectra) by comparison of both ${ }^{1} \mathrm{H}$ and ${ }^{13} \mathrm{C}$ data with those of other reports, and to distinguish signals from different molecules having similar proton chemical shifts but diverse ${ }^{13} \mathrm{C}$ signals. These experiments permit the complete and unambiguous identification of more than 50 metabolites (Table I) in 


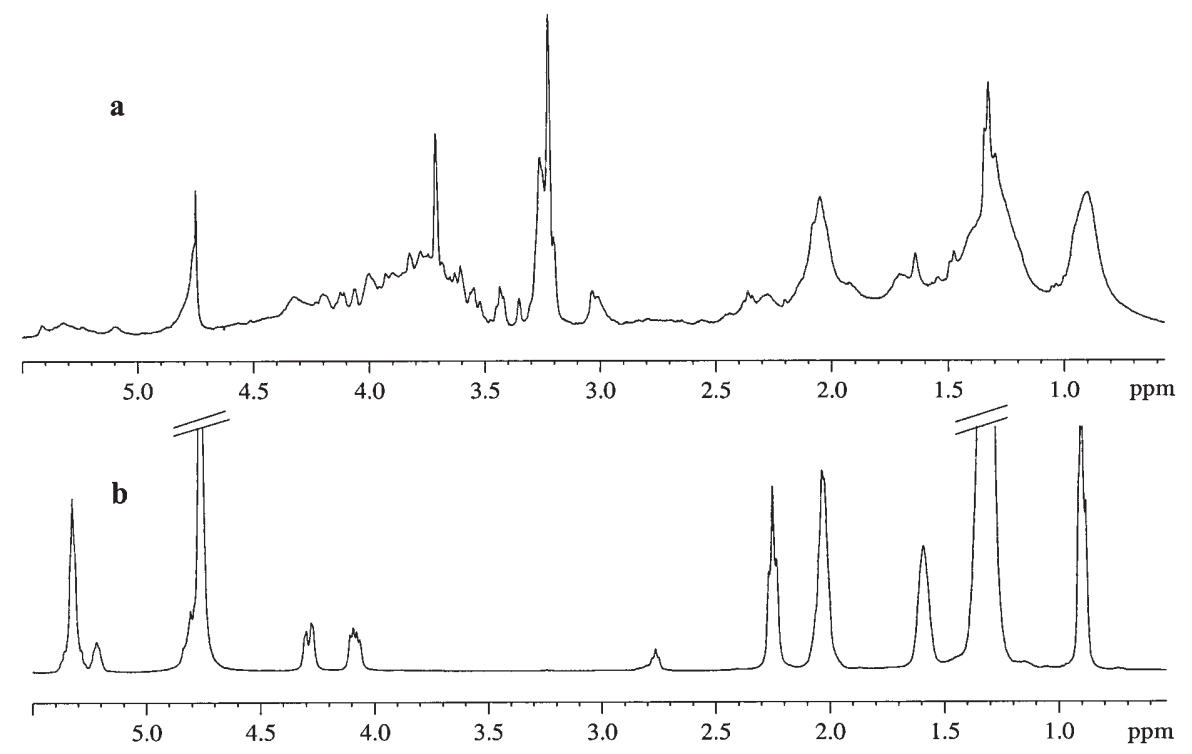

Figure 1. HR-MAS proton MR spectra of healthy (a) and neoplastic (b) samples.

healthy human tissues and to show metabolic changes in neoplastic human gastric mucosae.

As already observed, the ${ }^{1} \mathrm{H}$ MR spectra of gastric adenocarcinomas are dominated by the signals due to triglycerides. At first, we examined the types of fatty acids with the aim of characterising the relative content of saturated and unsaturated fatty acids.

Lipids. The proton spectrum of a neoplastic gastric mucosa, reported in Fig. 2, shows the resonance characteristics of triglycerides, confirmed by the presence of signals due to glycerol (5.26, 4.30 and $4.10 \mathrm{ppm}$ ) and to long fatty acid chains. All the examined adenocarcinomas ( 5 patients, for patient 2 , nine spectra were obtained from sampling in a different zone of the lesion tissues) showed a virtually identical spectral profile.

Signals at $2.02 \mathrm{ppm}$ are assigned to methylene protons of the $\mathrm{CH}_{2}-\mathrm{CH}=\mathrm{CH}$ moiety of mono- and poly-unsaturated fatty acids, whereas those at $2.78 \mathrm{ppm}$ are attributable to the methylene protons between two double bonds $\left(=\mathrm{C}-\mathrm{CH}_{2}-\mathrm{C}=\right)$ in poly-unsaturated acids. Furthermore, the unsaturated acids are identified by the signals at $5.33 \mathrm{ppm}$ due to the protons of the $-\mathrm{CH}=\mathrm{CH}-$ moiety.

The $\alpha$-linolenic acid is identified by the signal of the methyl protons at $0.96 \mathrm{ppm}$ and by its correlation with the methylene protons of the $\mathrm{CH}_{2}-\mathrm{CH}=\mathrm{CH}$ moiety at $2.06 \mathrm{ppm}$, detected in the COSY spectrum (Fig. 3).

The presence of linoleic acid is confirmed by the correlation between the triplet at $2.78 \mathrm{ppm}\left(=\mathrm{C}-\mathrm{CH}_{2}-\mathrm{C}=\right)$ and the signal at $2.02 \mathrm{ppm}\left(\mathrm{CH}_{2}-\mathrm{CH}=\mathrm{CH}\right)$ and by that with the signal at $5.33 \mathrm{ppm}(\mathrm{CH}=\mathrm{CH})$.

The analysis of the fat components, in the percentage of saturated, mono- and poly-unsaturated was performed through the integration of suitable signals: the starting point is represented by the integrated area of the $\mathrm{CH}_{2}(\alpha)$ to $\mathrm{C}=\mathrm{O}$ at $2.24 \mathrm{ppm}$. The percentage of unsaturated acids was evaluated by the ratio between the experimental and theoretical values of the integrated area of $\mathrm{CH}_{2}(\alpha)$ to double bond. The integrated area of $\mathrm{CH}_{2}(\alpha)$ to the double bond, due to monoand poly-unsaturated acids was corrected by the contribution of $\mathrm{CH}_{2}(\alpha)$ of linoleic and $\alpha$-linolenic acids, which is derived by the integrated area of the signal at $2.78 \mathrm{ppm}$, establishing that the ratio of mono- and poly-unsaturated components is ca.3:1, in all the examined samples. The $\alpha$-linolenic percentage was derived by the area of the terminal methyl signal at $0.96 \mathrm{ppm}$. The composition of triglycerides is reported in Table II.

Limited assessment can be made on the ${ }^{13} \mathrm{C}$ MR spectra obtained with HR-MAS technique. A carbon spectrum representative of all the samples analysed is displayed in Fig. 4.

The spectrum is of good quality, with a resolution comparable to that obtained in solution, permitting the evaluation of the composition of triglycerides. Three signals are present in the carbonyl region, at 172.26, 172.24 and at $171.97 \mathrm{ppm}$. The more deshielded signals are due to the carbonyls in the 1,3 positions $(s n 1,3)$ and the other to the carbonyl in the 2 position (sn2) of glycerol. The slight difference of the carbonyl resonances in $s n 1,3$ suggests that the triglycerides are mixed, even if no difference is observed in the $s n 2$ carbonyl resonance. The two groups of signals centered at 130.1 and $128.5 \mathrm{ppm}$ are due to olefinic carbons: In particular the latter are attributable to the internal carbons of the double bonds in linoleic and $\alpha$-linolenic acid, whereas the former are due to the carbons of mono-unsaturated acids and to external carbons of double bonds in linoleic and $\alpha$ linolenic acid.

The identification of saturated fatty acids is obtained by the resonances of the $\mathrm{CH}_{2} \mathrm{CH}_{3}$ moiety at 23.2 and $14.60 \mathrm{ppm}$, whereas that of mono-unsaturated and poly-unsaturated acids is deducible from the resonances of $\mathrm{CH}_{2}-\mathrm{CH}=\mathrm{CH}$ at 27.8 ppm, $\mathrm{CH}_{2} \mathrm{CH}_{3}$ at $23.3 \mathrm{ppm}$ and $14.56 \mathrm{ppm}$. The linoleic acid 
Table I. List of ${ }^{1} \mathrm{H}$ and ${ }^{13} \mathrm{C}$ chemical shift $(\delta$, ppm) of metabolites and exogenous molecules found in HR-MAS spectra of healthy and neoplastic tissue ${ }^{\mathrm{a}}$.

\begin{tabular}{|c|c|c|c|c|c|}
\hline Entry & Metabolite & $\delta{ }^{1} \mathrm{H}$ & $\delta^{13} \mathrm{C}$ & & Neoplastic ${ }^{\mathrm{b}}$ \\
\hline 1 & Fatty acids & $\begin{array}{l}0.89 \\
1.31 \\
1.59-1.60 \\
2.02 \\
2.24 \\
2.78 \\
5.30-5.32\end{array}$ & $\begin{array}{l}14.13-14.17 \\
29.4-32.2 \\
25.2 \\
27.8 \\
34.2 \\
26.2 \\
130.2 ; 128.4\end{array}$ & $\begin{array}{l}\mathrm{CH}_{3} \\
\left(\mathrm{CH}_{2}\right)_{\mathrm{n}} \\
\mathrm{CH}_{2}-\mathrm{C}-\mathrm{C}=\mathrm{O} \\
\mathrm{CH}_{2}-\mathrm{C}= \\
\mathrm{CH}_{2} \mathrm{C}=\mathrm{O} \\
=\mathrm{C}-\mathrm{CH}_{2}-\mathrm{C}= \\
\mathrm{CH}=\mathrm{CH}\end{array}$ & $\mathrm{y}$ \\
\hline 2 & Isoleucine & $\begin{array}{l}0.94(\mathrm{t}) \\
1.02(\mathrm{~d}) \\
1.29,1.48 \\
1.97 \\
3.69\end{array}$ & $\begin{array}{l}11.7 \\
15.5 \\
25.1\end{array}$ & $\begin{array}{l}\delta-\mathrm{CH}_{3} \\
\gamma-\mathrm{CH}_{3} \\
\gamma-\mathrm{CH}_{2} \\
\beta-\mathrm{CH} \\
\alpha-\mathrm{CH}\end{array}$ & trace \\
\hline 3 & Leucine & $\begin{array}{l}0.95(\mathrm{~d}) \\
0.97(\mathrm{~d}) \\
1.70 \\
1.72 \\
3.74\end{array}$ & $\begin{array}{l}21.5 \\
22.8 \\
40.4\end{array}$ & $\begin{array}{l}\delta-\mathrm{CH}_{3} \\
\delta-\mathrm{CH}_{3} \\
\gamma-\mathrm{CH} \\
\beta-\mathrm{CH}_{2} \\
\alpha-\mathrm{CH}\end{array}$ & trace \\
\hline 4 & Valine & $\begin{array}{l}0.99(\mathrm{~d}) \\
1.04(\mathrm{~d}) \\
2.25 \\
3.61\end{array}$ & $\begin{array}{l}17.3 \\
18.7 \\
\text { d }\end{array}$ & $\begin{array}{l}\gamma-\mathrm{CH}_{3} \\
\gamma-\mathrm{CH}_{3} \\
\beta-\mathrm{CH} \\
\alpha-\mathrm{CH}\end{array}$ & $\mathrm{y}$ \\
\hline 5 & Threonine & $\begin{array}{l}1.33(\mathrm{~d}) \\
4.26 \\
3.60\end{array}$ & $\begin{array}{l}20.3 \\
66.58 \\
61.22\end{array}$ & $\begin{array}{l}\gamma-\mathrm{CH}_{3} \\
\beta-\mathrm{CH} \\
\alpha-\mathrm{CH}\end{array}$ & trace \\
\hline 6 & Lactate & $\begin{array}{l}1.33(d) \\
4.11\end{array}$ & $\begin{array}{l}20.3 \\
69.1\end{array}$ & $\begin{array}{l}\mathrm{CH}_{3} \\
\mathrm{CH}\end{array}$ & $\mathrm{y}$ \\
\hline 7 & $\begin{array}{l}\text { Lidocaine } \\
\text { chlorohydrate }\end{array}$ & $\begin{array}{l}1.37(\mathrm{t}) \\
3.37(\mathrm{q}) \\
2.20(\mathrm{~s})\end{array}$ & $\begin{array}{l}9.2 \\
50.6 \\
17.8\end{array}$ & $\begin{array}{l}\mathrm{CH}_{3} \\
\mathrm{CH}_{2} \\
2,6-\mathrm{CH}_{3}\end{array}$ & \\
\hline 8 & B-Alanine & $\begin{array}{l}2.56 \\
3.18\end{array}$ & $\begin{array}{l}32.14 \\
40.01\end{array}$ & $\begin{array}{l}\mathrm{CH}_{2} \\
\mathrm{CH}_{2}\end{array}$ & \\
\hline 9 & Alanine & $\begin{array}{l}1.48(\mathrm{~d}) \\
3.78\end{array}$ & $\begin{array}{l}16.8 \\
51.1\end{array}$ & $\begin{array}{l}\beta-\mathrm{CH}_{3} \\
\alpha-\mathrm{CH}\end{array}$ & $\mathrm{y}$ \\
\hline 10 & Lysine & $\begin{array}{l}3.02(\mathrm{t}) \\
1.71 \\
1.48 \\
1.91 \\
3.79\end{array}$ & $\begin{array}{l}39.9 \\
27.1 \\
22.56 \\
30.6 \\
\mathrm{c}\end{array}$ & $\begin{array}{l}\varepsilon-\mathrm{CH}_{2} \\
\delta-\mathrm{CH}_{2} \\
\gamma-\mathrm{CH}_{2} \\
\beta-\mathrm{CH}_{2} \\
\alpha-\mathrm{CH}\end{array}$ & $\mathrm{y}$ \\
\hline 11 & Arginine & $\begin{array}{l}3.23 \\
1.69 \\
1.92 \\
3.78\end{array}$ & $\begin{array}{l}41.3 \\
28.1 \\
\mathrm{c}\end{array}$ & $\begin{array}{l}\delta-\mathrm{CH}_{2} \\
\gamma-\mathrm{CH}_{2} \\
\beta-\mathrm{CH}_{2} \\
\alpha-\mathrm{CH}\end{array}$ & \\
\hline 12 & Glutamate & $\begin{array}{l}2.36(t) \\
2.06,2.14 \\
3.77\end{array}$ & $\begin{array}{l}34.0 \\
27.9 \\
c\end{array}$ & $\begin{array}{l}\gamma-\mathrm{CH}_{2} \\
\beta-\mathrm{CH}_{2} \\
\alpha-\mathrm{CH}\end{array}$ & $\mathrm{y}$ \\
\hline 13 & Glutamine & $\begin{array}{l}2.44(\mathrm{td}) \\
2.14 \\
3.78\end{array}$ & $\begin{array}{l}31.5 \\
27.2 \\
c\end{array}$ & $\begin{array}{l}\gamma-\mathrm{CH}_{2} \\
\beta-\mathrm{CH}_{2} \\
\alpha-\mathrm{CH}\end{array}$ & trace \\
\hline
\end{tabular}


Table I. Continued.

\begin{tabular}{|c|c|c|c|c|c|}
\hline Entry & Metabolite & $\delta{ }^{1} \mathrm{H}$ & $\delta{ }^{13} \mathrm{C}$ & & Neoplastic $^{\mathrm{b}}$ \\
\hline 14 & Proline & $\begin{array}{l}3.43,3.34 \\
2.01 \\
2.34,2.07 \\
4.12\end{array}$ & & $\begin{array}{l}\delta-\mathrm{CH}_{2} \\
\gamma-\mathrm{CH}_{2} \\
\beta-\mathrm{CH}_{2} \\
\alpha-\mathrm{CH}\end{array}$ & \\
\hline 15 & Methionine & $\begin{array}{l}2.13(\mathrm{~s}) \\
2.62 \\
2.16 \\
3.87\end{array}$ & 14.9 & $\begin{array}{l}\mathrm{SCH}_{3} \\
\gamma-\mathrm{CH}_{2} \\
\beta-\mathrm{CH}_{2} \\
\alpha-\mathrm{CH}\end{array}$ & $\mathrm{y}$ \\
\hline 16 & Aspartic acid & $\begin{array}{l}2.68,2.82 \\
3.90\end{array}$ & 37.2 & $\begin{array}{l}\beta-\mathrm{CH}_{2} \\
\alpha-\mathrm{CH}\end{array}$ & \\
\hline 17 & Asparagine & $\begin{array}{l}2.85,2.96 \\
4.01\end{array}$ & 26.30 & $\begin{array}{l}\beta-\mathrm{CH}_{2} \\
\alpha-\mathrm{CH}\end{array}$ & \\
\hline 18 & Creatine & $\begin{array}{l}3.04(\mathrm{~s}) \\
3.92(\mathrm{~s})\end{array}$ & $\begin{array}{l}37.5 \\
54.5\end{array}$ & $\begin{array}{l}\mathrm{NCH}_{3} \\
\mathrm{CH}_{2}\end{array}$ & $\mathrm{y}$ \\
\hline 19 & Tyrosine & $\begin{array}{l}3.06,3.20 \\
3.93 \\
6.89 \\
7.23\end{array}$ & $\begin{array}{l}56.7 \\
116.5 \\
131.5\end{array}$ & $\begin{array}{l}\beta-\mathrm{CH}_{2} \\
\alpha-\mathrm{CH} \\
\text { Hortho } \\
\text { Hmeta }\end{array}$ & $\mathrm{y}$ \\
\hline 20 & Phenylalanine & $\begin{array}{l}3.11,3.28 \\
3.99 \\
7.34 \\
7.44 \\
7.37\end{array}$ & $\begin{array}{l}130.1 \\
129.6\end{array}$ & $\begin{array}{l}\mathrm{B}-\mathrm{CH}_{2} \\
\alpha-\mathrm{CH} \\
\text { Hortho } \\
\text { Hmeta } \\
\text { Hpara }\end{array}$ & $\mathrm{y}$ \\
\hline 21 & Ethanolamine & $\begin{array}{l}3.15(\mathrm{t}) \\
3.82(\mathrm{t})\end{array}$ & & $\begin{array}{l}\mathrm{CH}_{2} \\
\mathrm{CH}_{2}\end{array}$ & trace \\
\hline 22 & $\begin{array}{l}\text { Phosphory- } \\
\text { lethanolamine }\end{array}$ & $\begin{array}{l}3.23 \\
4.07\end{array}$ & $\begin{array}{l}41.1 \\
61.1\end{array}$ & $\begin{array}{l}\mathrm{CH}_{2} \\
\mathrm{CH}_{2}\end{array}$ & $\mathrm{y}$ \\
\hline 23 & $\begin{array}{l}\text { Glycerophosphory- } \\
\text { lethanolamine }\end{array}$ & $\begin{array}{l}3.30 \\
4.10\end{array}$ & & $\begin{array}{l}\mathrm{CH}_{2} \\
\mathrm{CH}_{2}\end{array}$ & \\
\hline 24 & Free choline & $\begin{array}{l}3.20 \\
3.53 \\
4.08\end{array}$ & $\begin{array}{l}54.6 \\
68.2 \\
56.5\end{array}$ & $\begin{array}{l}\mathrm{N}\left(\mathrm{CH}_{3}\right)_{3} \\
\mathrm{NCH} 2 \\
\mathrm{OCH} 2\end{array}$ & $\mathrm{y}$ \\
\hline 25 & $\begin{array}{l}\text { Glycerophosphoryl- } \\
\text { choline }\end{array}$ & $\begin{array}{l}3.22 \\
3.68 \\
4.33\end{array}$ & 54.7 & $\begin{array}{l}\mathrm{N}\left(\mathrm{CH}_{3}\right)_{3} \\
\mathrm{NCH}_{2} \\
\mathrm{OCH}_{2}\end{array}$ & \\
\hline 26 & Phosphorylcholine & $\begin{array}{l}3.22 \\
3.61 \\
4.22\end{array}$ & $\begin{array}{l}54.7 \\
67.3 \\
59.0\end{array}$ & $\begin{array}{l}\mathrm{N}\left(\mathrm{CH}_{3}\right)_{3} \\
\mathrm{NCH}_{2} \\
\mathrm{OCH}_{2}\end{array}$ & $\mathrm{y}$ \\
\hline 27 & ß-Glucose & $\begin{array}{l}4.67(\mathrm{~d}) \\
3.26 \\
3.49 \\
3.40 \\
3.47 \\
\mathrm{e}\end{array}$ & $\begin{array}{l}96.6 \\
74.8 \\
76.8 \\
69.9 \\
76.8 \\
\mathrm{e}\end{array}$ & $\begin{array}{l}1-\mathrm{CH} \\
2-\mathrm{CH} \\
3-\mathrm{CH} \\
4-\mathrm{CH} \\
5-\mathrm{CH} \\
6-\mathrm{CH}_{2}\end{array}$ & $\mathrm{y}$ \\
\hline 28 & Taurine & $\begin{array}{l}3.26(\mathrm{t}) \\
3.42(\mathrm{t})\end{array}$ & $\begin{array}{l}48.1 \\
35.9\end{array}$ & $\begin{array}{l}\mathrm{SCH}_{2} \\
\mathrm{NCH}_{2}\end{array}$ & $\mathrm{y}$ \\
\hline
\end{tabular}


Table I. Continued.

\begin{tabular}{|c|c|c|c|c|c|}
\hline Entry & Metabolite & $\delta{ }^{1} \mathrm{H}$ & $\delta{ }^{13} \mathrm{C}$ & & Neoplastic ${ }^{\mathrm{b}}$ \\
\hline 29 & Myoinositol & $\begin{array}{l}3.53(\mathrm{dd}) \\
4.06(\mathrm{t}) \\
3.63(\mathrm{t}) \\
3.30(\mathrm{t})\end{array}$ & $\begin{array}{l}71.8 \\
72.9 \\
73.1 \\
75\end{array}$ & $\begin{array}{l}1,3-\mathrm{CH} \\
2-\mathrm{CH} \\
4,6-\mathrm{CH} \\
5-\mathrm{CH}\end{array}$ & $\mathrm{y}$ \\
\hline 30 & Scylloinositol & $3.35(\mathrm{~s})$ & 54.6 & $\mathrm{CH}$ & $\mathrm{y}$ \\
\hline 31 & $\alpha$-Glucose & $\begin{array}{l}5.24(\mathrm{~d}) \\
3.54 \\
3.73 \\
3.42 \\
\mathrm{e}\end{array}$ & $\begin{array}{l}72.0 \\
70 \\
\mathrm{e}\end{array}$ & $\begin{array}{l}1-\mathrm{CH} \\
2-\mathrm{CH} \\
3-\mathrm{CH} \\
4-\mathrm{CH} \\
6-\mathrm{CH}_{2}\end{array}$ & $\mathrm{y}$ \\
\hline 32 & Glycine & 3.56 & 42.3 & $\mathrm{CH}_{2}$ & $\mathrm{y}$ \\
\hline 33 & PEG & 3.72 & 69.9 & & trace \\
\hline 34 & $\begin{array}{l}\text { Glycerol } \\
\text { (in lipids) }\end{array}$ & $\begin{array}{l}4.10,4.30 \\
5.26\end{array}$ & $\begin{array}{l}62.3 \\
69.8\end{array}$ & $\begin{array}{l}1,3-\mathrm{CH}_{2} \\
2-\mathrm{CH}\end{array}$ & $\mathrm{y}$ \\
\hline 35 & Glycerol & $\begin{array}{l}3.56,3.65 \\
3.81\end{array}$ & $\begin{array}{l}63.3 \\
72.7\end{array}$ & $\begin{array}{l}1-\mathrm{CH}_{2} \\
2-\mathrm{CH}\end{array}$ & \\
\hline 36 & $\begin{array}{l}\text { Bonded } \\
\text { glycerols }\end{array}$ & $3.95-3.70$ & 61.3 & $1,3-\mathrm{CH}_{2}$ & \\
\hline 37 & UDP & $\begin{array}{l}5.92 \\
4.35 \\
5.90(d) \\
7.89(d)\end{array}$ & & $\begin{array}{l}\text { 1-CHrib } \\
\text { 2-CHrib } \\
\text { 5-CHur } \\
\text { 6-CHur }\end{array}$ & \\
\hline 38 & Uracil & $\begin{array}{l}5.80(\mathrm{~d}) \\
7.54(\mathrm{~d})\end{array}$ & & $\begin{array}{l}\text { 5-CHur } \\
\text { 6-CHur }\end{array}$ & \\
\hline 39 & UMP & $\begin{array}{l}5.98 \\
4.37 \\
5.97(d) \\
8.11(d)\end{array}$ & & $\begin{array}{l}\text { 1-CHrib } \\
\text { 2-CHrib } \\
\text { 5-CHur } \\
\text { 6-CHur }\end{array}$ & \\
\hline 40 & Formiate & 8.48 & & $\mathrm{CH}$ & \\
\hline 41 & Adenosine & $\begin{array}{l}8.36(\mathrm{~s}) \\
8.23(\mathrm{~s})\end{array}$ & & $\begin{array}{l}2-\mathrm{CH} \\
8-\mathrm{CH}\end{array}$ & $\mathrm{y}$ \\
\hline 42 & Acetate & 1.92 & 24.8 & $\mathrm{CH}_{3} \mathrm{C}=\mathrm{O}$ & $\mathrm{y}$ \\
\hline 43 & Hypotaurine & $\begin{array}{l}2.65(\mathrm{t}) \\
3.35(\mathrm{t})\end{array}$ & $\begin{array}{l}38.73 \\
41.19\end{array}$ & $\begin{array}{l}\mathrm{CH}_{2} \\
\mathrm{CH}_{2}\end{array}$ & trace \\
\hline 44 & Tryptophane & $\begin{array}{l}7.73 \\
7.19 \\
7.29 \\
7.52\end{array}$ & & & \\
\hline 45 & $\alpha$ Glc-1-X & $\begin{array}{l}5.40 \\
3.61\end{array}$ & 100.2 & & \\
\hline 46 & Glutathione & $\begin{array}{l}4.57 \\
2.96 \\
3.80 \\
2.16 \\
2.55 \\
3.77 \\
8.57 \\
8.36\end{array}$ & $\begin{array}{l}56.18 \\
26.3\end{array}$ & $\begin{array}{l}\gamma-\mathrm{CH}_{2}-\mathrm{Cys} \\
\beta-\mathrm{CH}_{2}-\mathrm{Cys} \\
\alpha-\mathrm{CH}-\mathrm{Glu} \\
\beta-\mathrm{CH}_{2}-\mathrm{Glu} \\
\gamma-\mathrm{CH}-\mathrm{Glu} \\
\text { Gly } \\
\mathrm{NH}-\mathrm{Cys} \\
\text { NH-Gly }\end{array}$ & \\
\hline
\end{tabular}


Table I. Continued.

\begin{tabular}{|c|c|c|c|c|c|}
\hline Entry & Metabolite & $\delta{ }^{1} \mathrm{H}$ & $\delta{ }^{13} \mathrm{C}$ & & Neoplastic ${ }^{b}$ \\
\hline 47 & ß-OH-butyrate & $\begin{array}{l}1.18 \\
4.14\end{array}$ & & $\mathrm{CH}_{3}$ & $\mathrm{y}$ \\
\hline 48 & Succinate & $2.41(\mathrm{~s})$ & & $\alpha, \beta-\mathrm{CH}_{2}$ & $\mathrm{y}$ \\
\hline 49 & Histidine & $\begin{array}{l}7.78(\mathrm{~s}) \\
7.05(\mathrm{~s})\end{array}$ & & $\begin{array}{l}2-\mathrm{CH} \\
4-\mathrm{CH}\end{array}$ & $\mathrm{y}$ \\
\hline 50 & Ascorbate & $\begin{array}{l}4.52(\mathrm{~d}) \\
4.01\end{array}$ & & $\begin{array}{l}4-\mathrm{CH} \\
5-\mathrm{CH}\end{array}$ & \\
\hline 51 & Unknown & 1.63 & 23.5 & & \\
\hline 52 & Unknown & $\begin{array}{l}2.44 \\
3.44\end{array}$ & & & \\
\hline 53 & Bonded Thr & $\begin{array}{l}1.22 \\
4.24 \\
4.31\end{array}$ & 16.2 & $\begin{array}{l}\gamma-\mathrm{CH}_{3} \\
\beta-\mathrm{CH} \\
\alpha-\mathrm{CH}\end{array}$ & \\
\hline 54 & Bonded Ala & $\begin{array}{l}1.41 \\
4.32\end{array}$ & 17.1 & $\begin{array}{l}\beta-\mathrm{CH}_{3} \\
\alpha-\mathrm{CH}\end{array}$ & \\
\hline 55 & Bonded Val & $\begin{array}{l}0.93 \\
2.08 \\
4.11\end{array}$ & 23 & $\begin{array}{l}\gamma-\mathrm{CH}_{3} \\
\beta-\mathrm{CH} \\
\alpha-\mathrm{CH}\end{array}$ & \\
\hline 56 & Cetylpyridinium & $\begin{array}{l}5.08 \\
2.03\end{array}$ & & $\begin{array}{l}\mathrm{NCH}_{2} \\
\mathrm{~B}-\mathrm{CH}_{2}\end{array}$ & \\
\hline
\end{tabular}

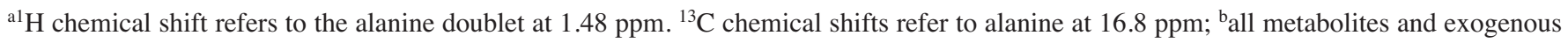
molecules were found in healthy gastric mucosa. In this column are also shown those found in the neoplastic tissues; c, C $\alpha$ contributes to the 3.77, 55.1 ppm cross-peak; d, $\mathrm{C} \alpha$ contributes to the 3.61, 61.1 ppm cross-peak; e, contributes to the broad correlation between $\mathrm{CH}_{2}$ protons in the region $3.9 \div 3.6 \mathrm{ppm}$ and carbons around $62 \mathrm{ppm}$ in the HSQC spectra.

is clearly identified by the resonance of $=\mathrm{C}-\mathrm{CH}_{2}-\mathrm{C}=$ at 26.1 ppm. The ${ }^{13} \mathrm{C}$ resonance of the $\alpha$-linolenic acid was not detected due to its low level.

The MRS data of lipids obtained through the MR analysis is reported in Table III.

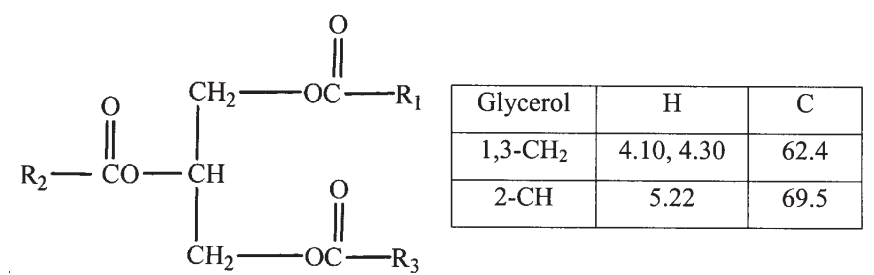

Triglyceride

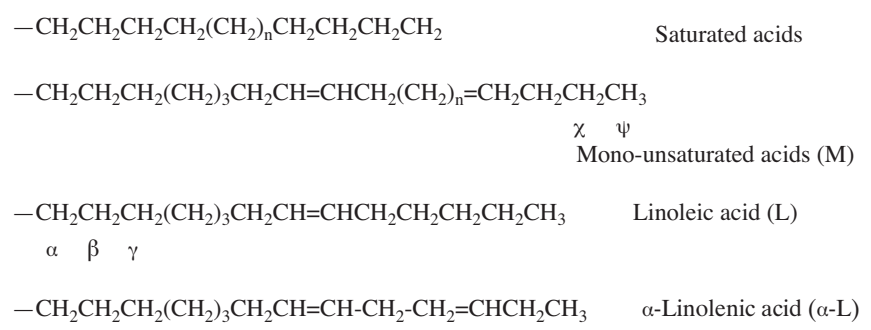

Scheme 1. Triglycerides and relative numbering.
The assignment of ${ }^{13} \mathrm{C}$ MR signals of the triglycerides was made through the ${ }^{1} \mathrm{H},{ }^{13} \mathrm{C}$ HSQC experiment and by comparison with literature data (22). The detection of lipids in all the gastric adenocarcinomas examined differentiates them from healthy mucosa in which their amounts are very low. This finding is in opposition with that of Mun et al (10) who reported a decreased level of lipids in gastric adenocarcinomas detected from low resolution ex vivo MR spectrum of the composite mucosal/submucosal layer.

Research on the lipidic component of cells and tissues recognised them as having a fundamental role in cell life and death (23), and analytical studies performed by spectroscopic techniques have gained importance. Indeed, deposits of neutral lipids in human cells and tissues have been revealed and identified by MRS. Some authors have speculated that ${ }^{1} \mathrm{H}$ resonances, attributed to mobile lipids, originate from lipid droplets made of triglycerides and cholesteryl esters located both in the cytoplasm $(24,25)$ and in the plasma membrane (26). The importance of these ${ }^{1} \mathrm{H}$ visible lipids in the life and death of cells has been highlighted by Hakumaki and Kauppinen (23) and the direct relationship between Nuclear Magnetic Resonance-visible lipids, lipid droplets and cell proliferation has been demonstrated by Barba et al 


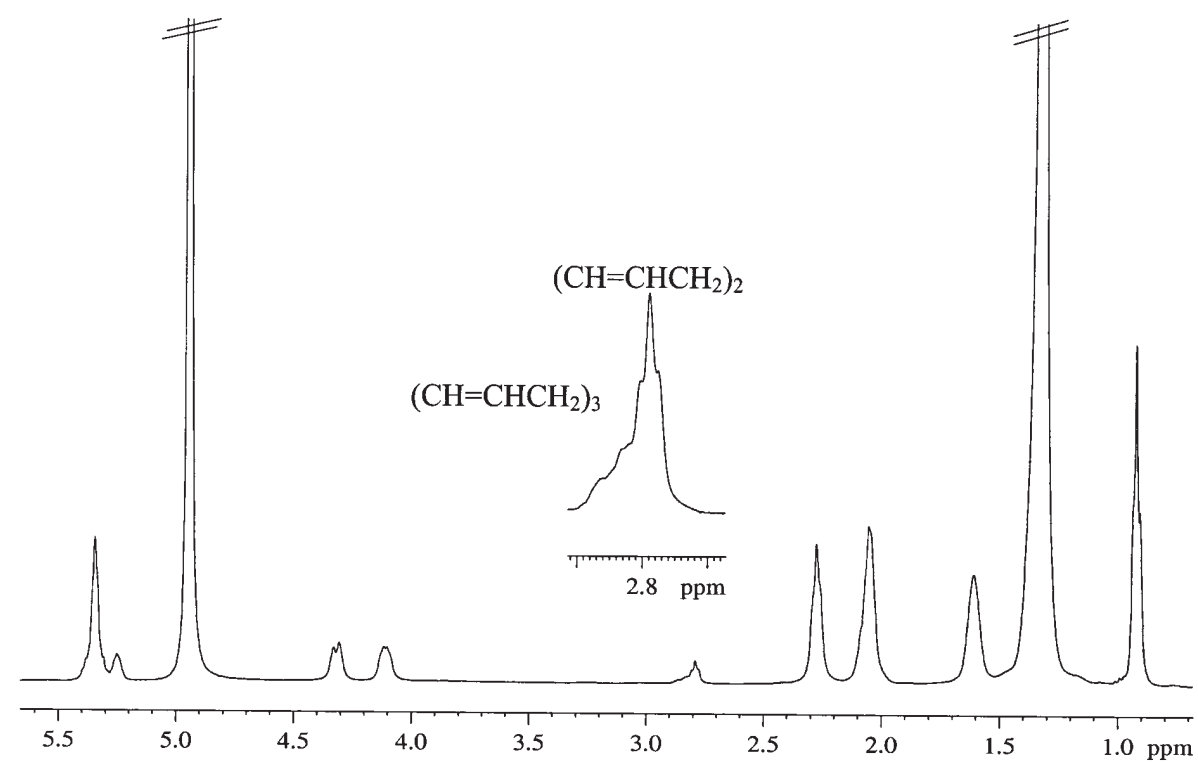

Figure 2. ${ }^{1} \mathrm{H}$ HR-MAS MR spectrum of cancerous gastric mucosa.

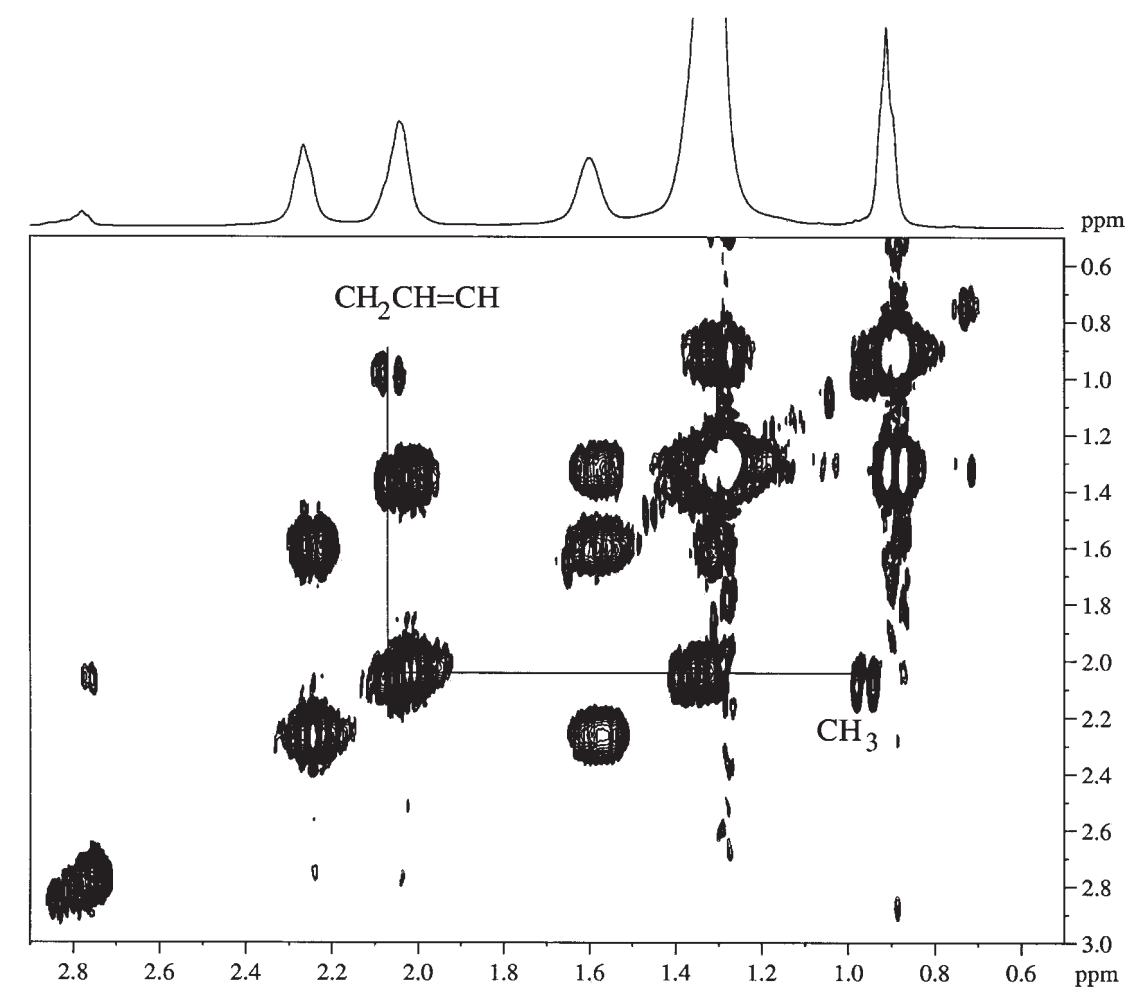

Figure 3. COSY spectrum of sample 2. The correlation $\mathrm{CH}_{2}-\mathrm{CH}_{3}$ of $\alpha$-linolenic acid is shown.

(27). Moreover, a positive correlation between the presence of lipid droplets detected in vivo by MRS and necrosis in rat brain glioma has been reported (28). All of this evidence shows how these lipid droplets, formed mainly by triglycerides, are closely involved in the various aspects of tumor cell transformation.

In agreement with the above findings, we have detected many triglycerides in all the examined adenocarcinomas collected by endoscopy or surgery. High amounts of lipids in clear cell renal carcinoma samples were detected, by ex vivo
HR-MAS MRS, by Tate et al (29). Our results therefore are not surprising even if ultra-structural further investigations are needed to better elucidate the localization of these compounds and to understand their role and significance in gastric adenocarcinomas.

Low molecular-weight metabolites in gastric adenocarcinoma. The CPMG experiment permits the attenuation of the signal due to lipids and to show the signals arising from small metabolites in the neoplastic tissue; in this type of 
Table II. Percentage of different fatty acid components in the adenocarcinoma samples.

\begin{tabular}{lcccc}
\hline & & \multicolumn{2}{c}{ Unsaturated } \\
\cline { 3 - 5 } Patients & Saturated & $\begin{array}{c}\text { Mono- } \\
\text { unsaturated }\end{array}$ & \multicolumn{2}{c}{$\begin{array}{c}\text { Poly- } \\
\text { unsaturated }\end{array}$} \\
\cline { 3 - 5 } & & & Linoleic $\alpha$-Linolenic \\
\hline 1 & $20 \%$ & $64 \%$ & $14 \%$ & $2 \%$ \\
2 & $28 \%$ & $56 \%$ & $13 \%$ & $3 \%$ \\
3 & $23 \%$ & $65 \%$ & $10 \%$ & $2 \%$ \\
5 & $26 \%$ & $48 \%$ & $24 \%$ & $2 \%$ \\
\hline
\end{tabular}

sample a good CPMG spectrum, i.e. a good suppression of lipid resonances, can be obtained using a total spin-echo time of $720 \mathrm{msec}$. The corresponding spectrum is reported in Fig. 5.

Some metabolites can be identified by the comparison with the corresponding healthy tissues. In particular, adenosine, alanine (Ala), phenylalanine (Phe), tyrosine (Tyr), histidine (His), $\beta$-glucose ( $\beta$-Glc), $\alpha$-glucose $(\alpha-G l c)$, phosphorylcholine (PC, trace), myoinositol (Myo), phosphorylethanolamine (PE), glycine (Gly), taurine (Tau), hipotaurine (HTau), scyllo-inositol (Scy), choline containing compounds (ChoCC), free choline (Cho), ethanolamine (E), succinate (Suc), glutamine (Gln), glutamate (Glu), methionine (Met), acetate (Ac), hydroxibutyrate (OH-But), valine (Val) and low amounts of isoleucine (Ile) and leucine (Leu), are recognizable. Polyethylen glicole (PEG) was present in small amounts in only some samples.

Different relative ratios of metabolites were found in the healthy and neoplastic tissues as is clearly evident in the two spectra reported in Fig. 6.

At a glance, the major differences are found in the increased amount of Gly in neoplastic tissues with respect to the healthy ones. It has been suggested that the intermediates of a more bioactive glycolitic pathway in neoplasms are responsible for the increase in Gly amounts, involving phosphoglycerate and serine (30). In agreement with these findings, several authors reported Gly as the most notable peculiarity in glioblastomas $(31,32)$ and breast tumors (29). Moreover, in the case of breast tumors, high amount of Gly were correlated to tumor size, cellularity and the presence of positive lymph node (33).

Another difference, recurrent in all the examined adenocarcinomas, besides the change in the ChoCC:Cr ratio which passes from $16: 1$ in all the healthy samples to $2.5: 1$ in the neoplastic ones, is found in the relative abundance of Cho with respect to ChoCC. Healthy gastric mucosa is characterised by high amount of PC and low amounts of Cho and GPC, with a mean Cho:ChoCC ratio of 1:5. Instead, the adenocarcinoma samples were characterised by large amounts of Cho and very low amounts of PC and GPC with a mean ratio Cho:ChoCC of $4: 1$.

PEG is a component of the anesthetic formulation administered to patients before endoscopy, and its presence was detected, through the strong singlet at $3.72 \mathrm{ppm}$ only in healthy gastric mucosa; whereas it is absent or only in traces in all the gastric adenocarcinoma samples. It is interesting to note that this molecule is preferentially fixed in the healthy tissues only.

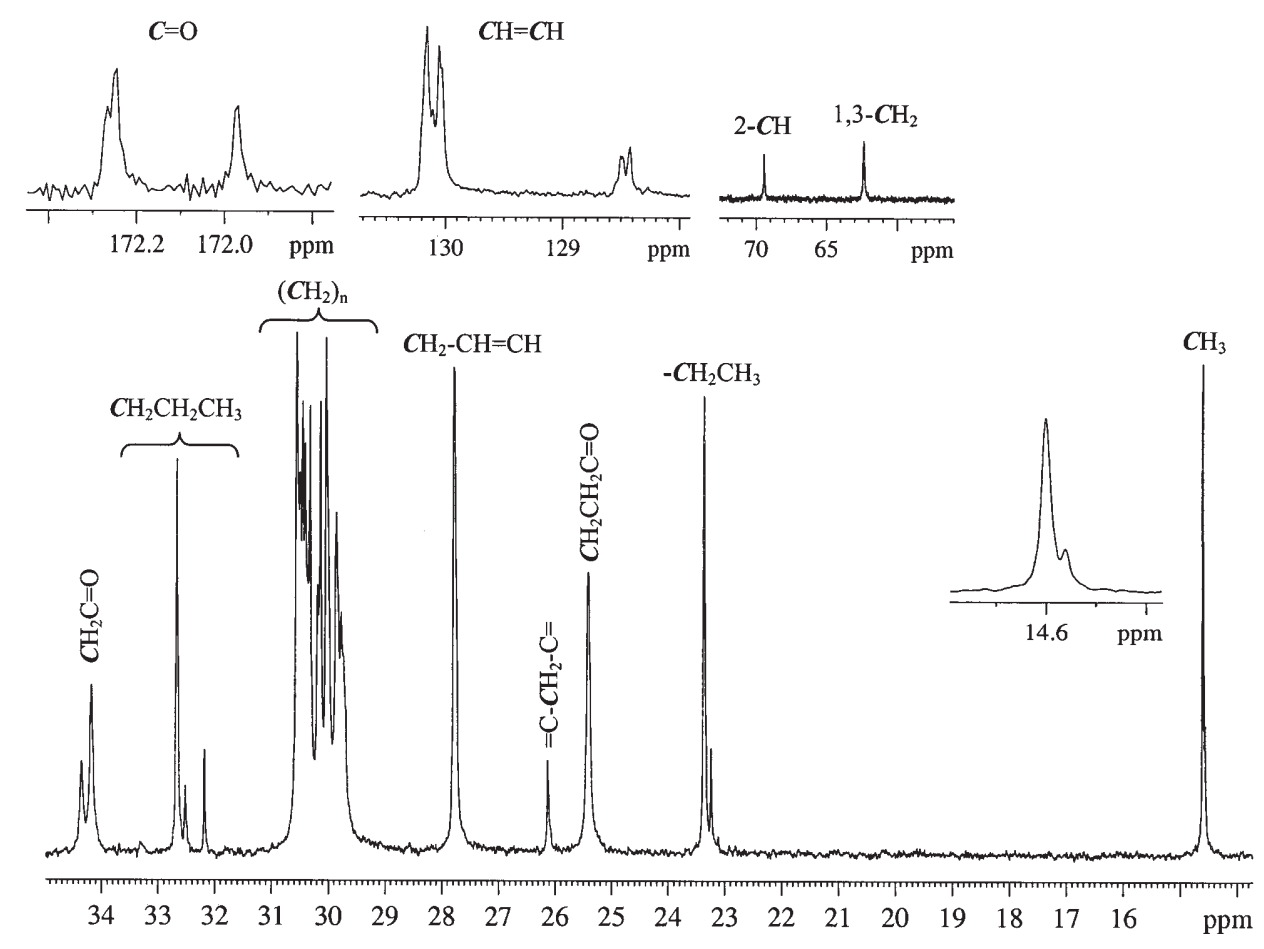

Figure 4 . The ${ }^{13} \mathrm{C}$ spectrum of patient 2 biopsy. 
Table III. NMR data $\left({ }^{1} \mathrm{H},{ }^{13} \mathrm{C}\right)$ of fatty acids in neoplastic gastric mucosa.

\begin{tabular}{|c|c|c|c|c|c|c|c|c|c|c|}
\hline & $\mathrm{C}=\mathrm{O}$ & $\mathrm{CH}_{2}(\alpha)$ & $\mathrm{CH}_{2}(ß)$ & $\left(\mathrm{CH}_{2}\right)_{\mathrm{n}}$ & $\mathrm{CH}_{2} \mathrm{CH}=\mathrm{CH}$ & $\mathrm{CH}=\mathrm{CH}$ & $=\mathrm{C}-\mathrm{CH}_{2}-\mathrm{C}=$ & $\mathrm{CH}_{2}(\chi)$ & $\mathrm{CH}_{2}(\psi)$ & $\mathrm{CH}_{3}$ \\
\hline $\mathrm{C}$ & $\begin{array}{l}172.26 \\
172.24 \\
171.97\end{array}$ & $\begin{array}{l}34.2 \\
34.3\end{array}$ & 25.5 & $29.7 \div 30.6$ & $27.8(\mathrm{M}+\mathrm{L})$ & $\begin{array}{l}130.1 \\
128.5\end{array}$ & $26.1(\mathrm{~L})$ & $\begin{array}{l}32.65, \\
32.51, \\
32.18(\mathrm{~S})\end{array}$ & $\begin{array}{l}23.3(\mathrm{M}+\mathrm{L}), \\
23.2(\mathrm{~S})\end{array}$ & $\begin{array}{l}14.60(\mathrm{M}+\mathrm{L}) \\
14.56(\mathrm{~S})\end{array}$ \\
\hline $\mathrm{H}$ & & 2.24 & - & 1.60 & $\begin{array}{l}2.02, \\
2.06(\alpha-L)\end{array}$ & 5.33 & $\begin{array}{l}2.78(\mathrm{~L}) \\
2.81(\alpha-\mathrm{L})\end{array}$ & \multicolumn{2}{|c|}{$1.28 \div 1.32$} & $\begin{array}{l}0.89 \\
0.96(\alpha-\mathrm{L})\end{array}$ \\
\hline
\end{tabular}

For numbering see Scheme 1.
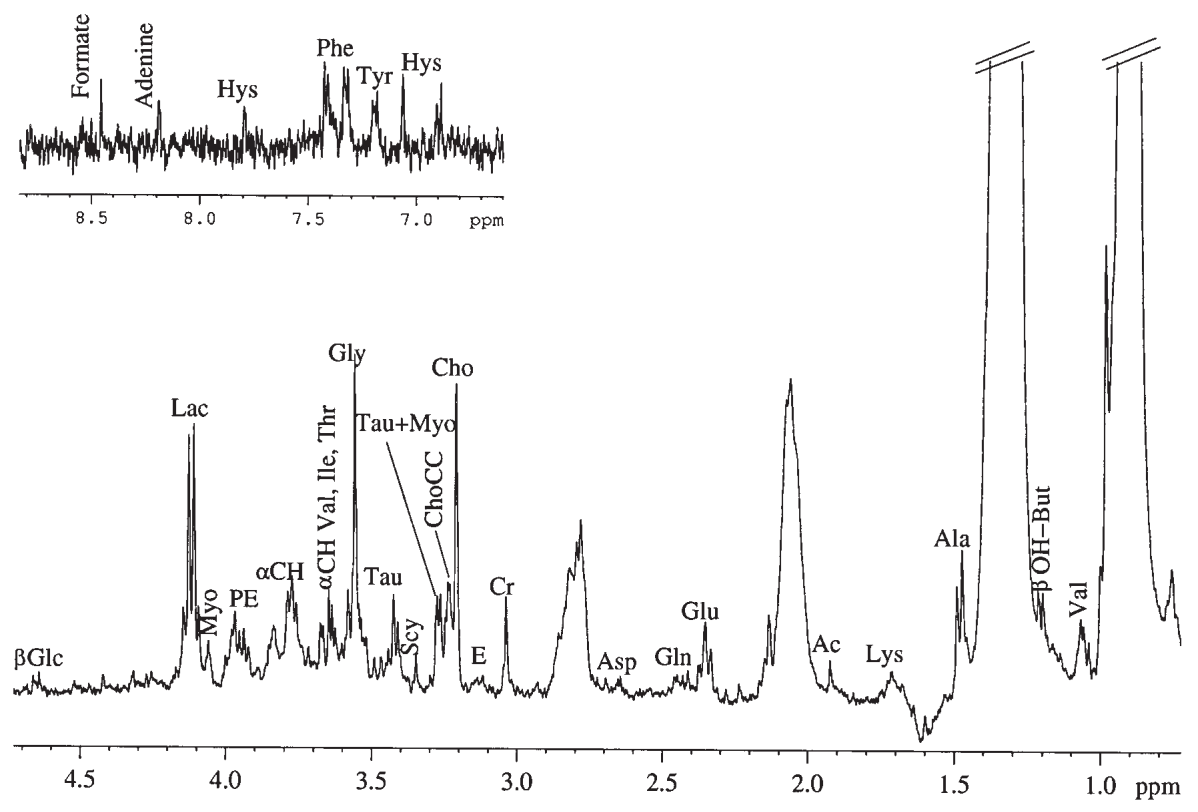

Figure 5. The CPMG spectrum of gastric adenocarcinoma tissue.

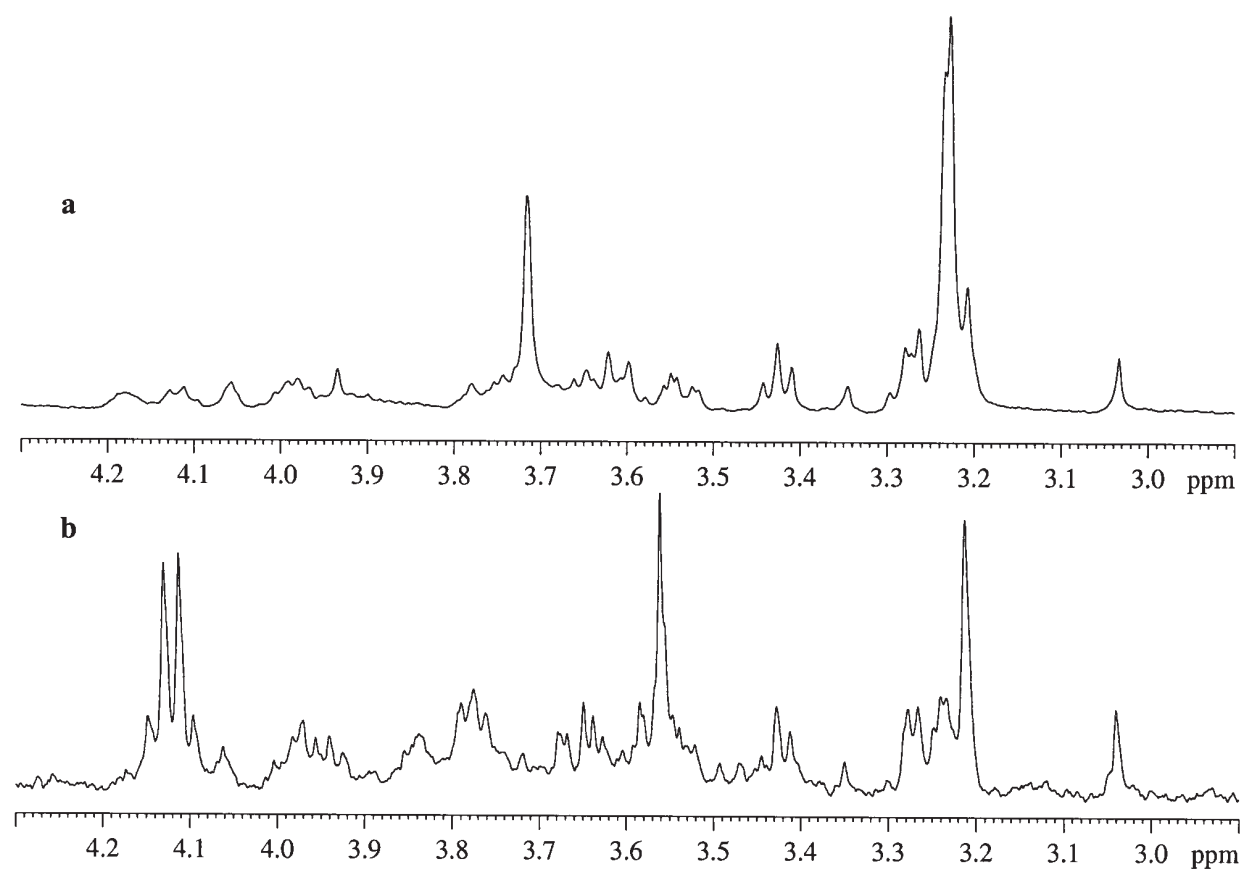

Figure 6. The CPMG spectra of healthy gastric mucosa (trace a) and adenocarcinoma (trace b). 
In conclusion, this report represents the first study performed through HR-MAS MRS on ex vivo specimens of human gastric adenocarcinomas. We characterised the molecular pattern of neoplastic mucosa and compared it with that of healthy gastric tissue.

The knowledge of the metabolic profile of healthy and gastric tumoral tissues could be the basis for the application of the in vivo MR spectroscopy for diagnostic purposes.

\section{Acknowledgements}

The Fondazione Cassa di Risparmio di Modena is greatly acknowledged for the financial support given for the acquisition of the Bruker Avance400 Spectrometer and the Centro Interdipartimentale Grandi Strumenti of the University of Modena and Reggio Emilia is greatly acknowledged for the use of it. This study was supported by grants of MURST (ex 60\%) to V.T.

\section{References}

1. Murray CJ and Lopez AD: Alternative projections of mortality and disability by cause 1990-2000: Global Burden of Disease Study. Lancet 349: 1494-1504, 1997.

2. Correa P: Human gastric carcinogenesis. A multistep and multifactorial process. Cancer Res 52: 6735-6740, 1992.

3. Danesh J: Helicobacter pylori infection and gastric cancer: systematic review of the epidemiological studies. Aliment Pharmacol Ther 13: 851-856, 1999.

4. Rudy DRA and Zdon MJ: Update on colorectal cancer. Am Fam Physician 61: 1759-1769, 2000.

5. Kwoch L, Smith JK, Castillo M, et al: Clinical applications of proton MR Spectroscopy in oncology. Technol Cancer Res Treat 1: 17-28, 2002.

6. Tosi R and Tugnoli V (eds): Nuclear Magnetic Resonance Spectroscopy in the Study of Neoplastic Tissue. Nova Science Publishers Inc., New York, 2005.

7. Gillies RJ and Morse DL: In vivo Magnetic Resonance Spectroscopy in cancer. Ann Rev Biomed Eng 7: 287-326, 2005.

8. Smith ICP and Steward LC: Magnetic resonance spectroscopy in medicine: clinical impact. Progr Nucl Magn Spect 40: 1-34, 2002.

9. Tugnoli V, Mucci A, Schenetti L, Calabrese C, Di Febo G, Rossi MC and Tosi MR: Molecular characterization of human gastric mucosa by HR-MAS magnetic resonance spectroscopy. Int J Mol Med 14: 1065-1071, 2004.

10. Mun CW, Cho JY, Shin WJ, et al: Ex vivo proton MR spectroscopy $\left({ }^{1} \mathrm{H}-\mathrm{MRS}\right)$ for evaluation of human gastric carcinoma. Magn Reson Imaging 22: 861-870, 2004.

11. Tugnoli V, Schenetti L, Mucci A, et al: A comparison between in vivo and ex vivo HR-MAS ${ }^{1} \mathrm{H}$ MR spectra of a pediatric posterior fossa lesion. Int J Mol Med 16: 301-307, 2005.

12. Goeseki N, Takizawa T and Koike M: Differences in the mode of extension of gastric cancer classified by histological type: new histological classification of gastric carcinoma. Gut 33: 606-612, 1992.

13. Bax A: A spatially selective composite $90^{\circ}$ radiofrequency pulse. J Magn Reson 65: 142-145, 1985.

14. Meiboom S and Gill D: Modified spin-echo method for measuring nuclear relaxation time. Rev Sci Instrum 29: 688-691, 1958.
15. Wu D, Chen A and Johnson Jr CS: An improved diffusionordered spectroscopy experiment incorporating bipolar gradient pulses. Magn Reson Series A 115: 260-264, 1995.

16. Jeener J: Pulse pair techniques in high resolution NMR. Ampere International Summer School II, Basko Polje, Yugoslavia, 1971

17. Aue WP, Bartholdi E and Ernst RR: Two-dimensional spectroscopy. Application to nuclear magnetic resonance. J Chem Phys 64: 2229-2246, 1976.

18. Braunschweiler L and Ernst RR: Coherence transfer by isotropic mixing: application to proton correlation spectroscopy. J Magn Reson 53: 521-528, 1983.

19. Bax A and Davis DG: MLEV-17-based two-dimensional homonuclear magnetization transfer spectroscopy. J Magn Reson 65: 355-360, 1985

20. Aue WP, Karhan J and Ernst RR: Homonuclear broad band decoupling and two-dimensional $J$-resolved NMR spectroscopy. J Chem Phys 64: 4226-4227, 1976.

21. Bodenhausen $G$ and Ruben DJ: Natural abundance nitrogen-15 NMR by enhanced heteronuclear spectroscopy. Chem Phys Lett 69: $185-189,1980$.

22. Mannina L, Luchinat C, Patumi M, Emanuele MC, Rossi E and Segre A: Concentration dependance of 13C NMR spectra of triglycerides: implications for the NMR analysis of olive oils. Magn Reson Chem 38: 886-890, 2000.

23. Hakumaki JM and Kauppinen RA: 1H NMR visibile lipids in the life and death of cells. Trends Biochem Sci 25: 357-362, 2000.

24. Callies R, Sri-Pathmanathan RA, Ferguson DYP and Brindle KM: The appearence of neutral lipid signals in the ${ }^{1} \mathrm{H}$ NMR spectra of a myeloma cell line correlates with the induced formation of cytoplasmatic lipid droplets. Magn Reson Med 29: 546-550, 1993.

25. Rèmy R, Fouilhè N, Barba I, Sam-Lai E, Lahrec H, Cucurella MG, et al: Evidence that mobile lipids detected in rat brain glioma by $1 \mathrm{H}$ nuclear magnetic resonance correspond to lipids droplets. Cancer Res 57: 407-414, 1997.

26. Ferretti A, Knijn A, Iorio E, Pulciani S, Giambenebetti M, Molinari A, et al: Biophysical and structural characterization of 1H-NMR-detectable mobile lipid domains in NIH-3T3 fibroblast. Biochem Biophys Acta 1438: 329-348, 1999.

27. Barba I, Cabanas ME and Arùs $\mathrm{C}$ : The relationship between nuclear magnetic resonance-visible lipids, lipid droplets and cell proliferation in cultured C6 cells. Cancer Res 59: 1861-1868, 1999.

28. Zoula S, Hèrigault G, Ziegler A, Farion R, Dècorps M and Remy C: Correlation between the occurrence of 1H-MRS lipid signal, necrosis and lipid droplets during C6 rat glioma development. NMR Biomed 16: 199-212, 2003.

29. Tate AR, Foxall PJD, Holmes E, Moka D, Spraul M and Nicholson JK: Distinction between normal and renal cell carcinoma kidney cortical biopsy samples using pattern recognition of ${ }^{1} \mathrm{H}$ magic angle spinning (MAS) NMR spectra. NMR Biomed 13: 64-71, 2000.

30. Peeling J and Sutherland G: High-resolution ${ }^{1} \mathrm{H}$ NMR spectroscopy studies on extracts of human cerebral neoplasms. Magn Reson Med 24: 123-136, 1992.

31. Kinoshita Y and Yokota A: Absolute concentrations of metabolites in human brain tumors using in vitro proton Magnetic Resonance Spectroscopy. NMR Biomed 10: 2-12, 1997.

32. Lehnardt FG, Bock C, Rohn G, Ernestus RI and Hoehn M: Metabolic differences between primary and recurrent human brain tumors: a ${ }^{1} \mathrm{H}$ NMR spectroscopic investigation. NMR Biomed 18: 371-382, 2005.

33. Sitter B, Lundgren S, Bathen Tone F, Halgunset J, Fjosne HE and Gribbestadt IS: Comparison of HR MAS MR spectroscopic profiles of breast cancer tissue with clinical parameters. NMR Biomed 19: 30-40, 2006. 